大規模スポーツイベントに参加するボランティアの組織市民行動促進要因の研究

ーボランティアリーダーのリーダーシップに着目してー ${ }^{\dagger}$

大 後 茂 雄* 大 後 栄 治**

\title{
Research on the Organization Citizen Action Promotion Factor of Volunteers Who Participated in a Large-scale Sporting Event: Volunteer Leader's Leadership ${ }^{\dagger}$
}

\author{
Shigeo DAIGO* and Eiji DAIGO**
}

\begin{abstract}
The Olympic Paralympic games will be held for the 2nd time in Tokyo in 2020. For this aim, important sporting events have been planned nationwide. In recent years, large-scale sporting events having 10,000 participants have been held in Japan. The participants in these sporting events are supported by many sports volunteers. As a feature of this sport volunteer activity, the volunteer leaders and volunteers who participate are unacquainted, Furthermore, it is an organization in which people meet for the first time on the day of the event. In this study, such an organization is referred to as a short-term set type organization. In this organization, adjustments or arrangements between volunteer leaders and volunteer members cannot be made sufficiently in advance. Therefore, it is expected that there may be situations in which people may work without a set role and in which the work they do cannot be predicted beforehand. In accordance with the theory of organizational behavior in recent years, a study of OCB (Organization Citizenship Behavior) was done. Organ (1983) defined OCB as behavior which does not require formal job behavior, and for which an organizational structure member performs organization citizen behavior. It is also considered to be behavior which promotes the effective function of an organization. Since this study was based on the results of only one event (Daigo 2017) it is necessary to refer to use research from previous studies. A questionnaire was distributed to a total of 650 leaders and volunteers, and they were directly returned to the researcher. As the result of analysis, it became clear that organization citizen behavior increased as the leaders gave supportive leadership to the volunteer individuals.
\end{abstract}

Key words : Organization Citizen Behavior, Syonan International Marathon Volunteer, Short-term Set Type Organization

\footnotetext{
†原稿受付 2019年 1 月 10 日 原稿受諾 2019年 5 月 23 日

$*$ 筑波大学大学院人間総合科学研究科 $\overline{7} 305-8577$ 茨城県つくば市天王台 $1-1-1$

$* *$ 神奈川大学人間科学部人間科学科 $=221-8686$ 神奈川県横浜市神奈川区六角橋 $3-27-1$

${ }^{*}$ Graduate School of Comprehensive Human Sciences, University of Tsukuba, 1-1-1, Tennodai, Tsukuba, Ibaraki, Japan (305-8577)

** Department of Human Sciences, Faculty of Human Sciences, Kanagawa University, 3-27-1, Rokkakubashi, Kanagawa-ku, Yokohama, Kanagawa, Japan (221-8686)
} 


\section{1. 緒} 言

東京で 2 回目の開催となる東京2020オリン ピック・パラリンピック競技大会（以下「東京 2020大会」という）が開催される。世界200以 上の国や地域から選手や関係者が参加し, 多く の観客が日本を訪れることになる，さらに，東 京2020大会はテレビやインターネット配信を通 じて48億人が観戦すると言われており，世界中 の人々へ日本の魅力を伝えインバウンドを生む 絶好の機会となるスポーツイベントになる.

これを実現するため，東京2020大会では，よ り多くのボランティア参加者が必要不可欠とさ れる。公益財団法人東京オリンピック・パラリ ンピック競技大会組織委員 (以下「組織委員会」 という）は，ボランティアの業務内容を，(1)会 場内誘導・案内, (2)競技運営サポート, (3)ドラ イバー, (4)選手及び関係者アテンド業務, (5)工 ニフォーム配布, ID 発行サポート等の運営サ ポート業務，6急病人や病人をサポートするへ ルスケア業務, (7)通信機器貸出等のテクノロ ジー業務, 8メディアサポート業務, 9式典対 応等々としている. ボランティアの募集人数は 8 万人規模で, 活動期間は大会期間中及び大会 期間前後において 10 日間程度と比較的短期の活 動を予定している.

このように，国家的に重要なスポーツイベン 卜を控えるなか近年全国で参加者 10,000 人を超
える大規模なスポーツイベントが開催されてい る.これらスポーツイベントに参加する参加者 達は, 多くのスポーツボランティアによって支 えられている現状にある。このスポーツボラ ンティア活動は, 活動期間が限定的でかつ参加 するボランティアリーダーとボランティアはお 互い特段の面識もなく当日初めて顔を合わせる 者同士等が多く集まる組織である点に特徵があ る、本研究では, このような組織を短期集合型 組織と呼ぶこととする。この短期集合型組織で は, 構成されるボランティアリーダーとボラン ティアメンバー同士が事前に十分な打合せや準 備を行うことができないこともあり，活動中誰 の役割でもない仕事, あるいは事前に予測でき ない仕事が発生していることが予想される.

近年, 組織行動論において組織市民行動 (organization citizenship behavior) の研究が 進められており Organ ${ }^{1)}$ は, 組織市民行動を組 織構成員が行う行動のうち正式な職務の必要条 件ではない行動で，それによって組織の効果的 機能を促進する行動と定義した。尚, Organの 研究は企業や学校等の組織構成員を対象として いる.

この組織市民行動の概念を田中 ${ }^{2)}$ 基に図 $1 \mathrm{a}$, 図 $1 \mathrm{~b}$ に示す．職場で生じる全ての業務をWで 表し職場で働く組織構成員の職務を, 職務分掌 の規定により $\mathrm{A} 氏 ， \mathrm{~B}$ 氏， C氏へ割り当て楕円 で表した。この時点で誰の役割でもない仕事は

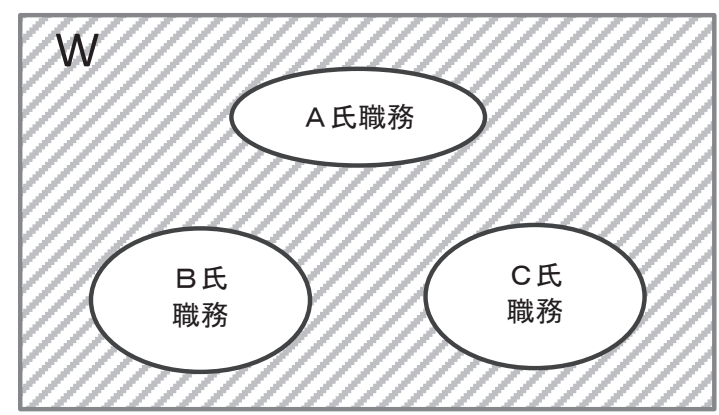

図 $1 \mathrm{a}$ 職場内での従業員の職務範囲：職務分掌が明 確な場合

田中（2004）より筆者作成

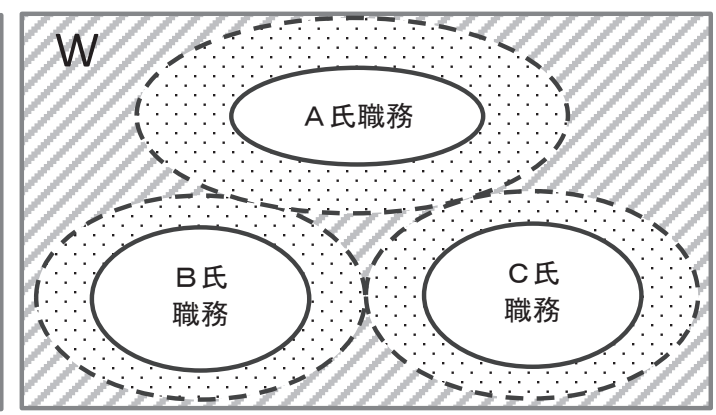

図 $1 \mathrm{~b}$ 職場内での従業員の職務範囲：自発的な職 務が生じた場合

田中（2004）より筆者作成 
斜線部となる。組織が機能していく限り新しい 仕事は継続的に発生し続けるものであり, これ らの仕事の全てを網羅し組織構成員へ事前に割 り当てることは不可能である。しかし，割り当 てられない仕事を放置していれば組織が円滑に 機能しなくなる恐れがある，従って，この誰の 役割でもない仕事は, 組織構成員の誰かがやら なければ組織は機能しないため, 組織構成員は 組織のために自己の職務範囲や役割を超えた仕 事（図 $1 \mathrm{~b}$ ドット部）を自発的に行い, 斜線部 の範囲を極力無くし組織に与えられた業務の隙 間を埋めていく必要がある。この隙間を埋める 行動が組織市民行動の概念である。

次に, この組織市民行動を規定する要因は いくつかあるが, Smith et al. ${ }^{3)}$ や Konovsky, \& $\mathrm{Pugh}^{4)}$ は, 組織市民行動を生起させる直接的 要因として上司への信頼感を見出しており, 本 研究に例えればボランティアリーダーが上司に 当たることから本研究においても重要な説明変 数になる可能性があると考えられる.

また，これまでの米国や国内における組織市 民行動の先行研究は, 企業や学校等の継続的に 雇用されている組織構成員の行動を研究対象と し多くの研究結果を蓄積しているが，スポーツ イベントボランティアのような短期集合型の組 織を対象とした研究は十分になされていない現 状にある。このスポーツイベントボランティア のような短期集合型の組織においても職務の全 てを網羅し事前にメンバーに割り当てる事は, 組織構成員が継続的に雇用されている組織以上 に困難であることが予想され，事前に割り当て られない仕事を放置していれば大会運営に支障 をきたす恐れがある。従って, 短期集合型組織 であるスポーツイベントの円滑な運営のために も, スポーツイベントボランティアの活動中ボ ランティアリーダーがどのようなリーダーシッ プを発揮するとボランティアの組織市民行動が 促進されるのかを明らかにすることは非常に重 要と捉え, その運営に活かすことが不可欠であ ると考えられる.

そこで, 本研究では, スポーツイベントボラ
ンティアに参加するボランティアの組織市民行 動の促進要因について, ボランティアリーダー のリーダーシップスタイルに焦点を当てて明ら かにすることを目的とする.

本研究における調查対象箇所は, 国内で開催 される短期集合型組織であるスポーツイベント ボランティア活動のうち, 選手受付, 選手誘導, 救護, 給水等それぞれ決められた業務があり, ボランティアは事前に割り振られた業務以外に 大会参加者から役割外の問合せを受けたり，苦 情を受けたり，また給水所では数百人単位のラ ンナーが一気に押し寄せるため, 誰の役割でも ない仕事，あるいは事前に予測できなかった仕 事が発生する大会を選考する事とした，大会規 模が大きくなれば誰の役割でもない仕事, ある いは事前に予測できない仕事が継続的に発生す ることが予想される事から都市部で開催される 大規模マラソンイベントボランティアを対象と し, 具体的には 24,000 人が参加する神奈川県湘 南エリアで開催される湘南国際マラソンのボラ ンティア組織を調査対象とした。

\section{2. 先行 研 究}

\section{1 組織市民行動の定義}

組織市民行動の先行研究は欧米を中心に行わ れてきたが, 米国で組織市民行動の研究が始 まった理由の一つに, 田中 ${ }^{2)}$ は企業や組織では 誰の役割でもない仕事が多く, 職務記述書だけ では円滑に業務が遂行できないという米国企業 の反省があったのではないかと述べている．欧 米の多くの企業は職務記述書による契約形態 であるため, 誰の役割でもない仕事が発生した 際にその仕事を誰も行わなければ企業の組織は 機能不全に陥ることになる，組織の業務は必ず しも職務に規定されたものばかりではなく，な かには職務として規定されていない業務もあ るが, それらの業務をこなす事で組織の社会 的機能が円滑になっているのである（Katz，\& Kahn, ${ }^{5)}$ ).

この組織市民行動 (organization citizenship behavior）という言葉を初めて使ったのは, 
Smith, Organ, \& Near ${ }^{3)}$ であり, 協力, 有用 性, 示唆, 善意の姿勢, 愛他主義による無数の 行為そのものが組織市民行動であると述べてい る.そして，この組織市民行動を明確に定義し

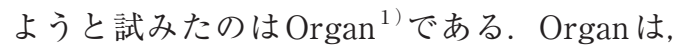
組織市民行動を「従業員が行う任意の行動のう ち, 彼らにとって正式な職務の必要条件ではな い行動で, それによって組織の効果的機能を促 進する行動とし, その行動は強制的に任された ものではなく，正式な給与体系によって補償さ れるものでもない」と定義している.さらに, Podsakoff, MacKenzie, \& Hui ${ }^{6)}$ は, 組織市民行 動には役割内行動は含まれないとし, 以下の条 件を満たすものと定義した。

(1)従業員が（組織市民行動を）示した事に対 してはっきりと褒賞されるわけではなく, 示さ なかったことに対して罰せられることのないも の. (2)従業員の職務内容規定には含まれないも の. (3)従業員が彼らの仕事の1つとして行うよ うに訓練されていないもの.

\section{2 組織市民行動の構成概念と測定尺度}

組織市民行動の構成概念を測定する尺度につ いてSmith et al. ${ }^{3)}$ は, 経営者インタビューに 基づいて16項目からなる組織市民行動尺度を構 成し, 愛他主義（altruism）因子と一般化され た服従（generalized compliance）因子の 2 因 子を導いた。

さらにOrgan ${ }^{1)}$ は, 組織市民行動が(1)愛他 主義, (2)誠実さ, (3)スポーッマンシップ, (4) 礼儀正しさ, (5)市民美徳の5つの側面から構 成されていると仮定した。その後, Podsakoff, MacKenzie, Moorman, \& Fetter ${ }^{7)}$ らがOrgan ${ }^{1)}$ の構成概念の定義に基づき項目を作成して分析 を行った結果, 24項目項目 5 因子で構成される 多次元的尺度を開発した。 その後もVan Dyne, Graham, \& Dienesch ${ }^{8}$ らが 5 因子モデル（忠 誠, 服従, 社会的参加, 自主的参加, 機能的参 加）を見出している。この他にも組織市民行動 の尺度については多様な研究がある.

これに対し, 日本における組織市民行動の研
究はどのようなものなのか. 日本企業の従業員 に拈いては，既に自ら進んで自分の会社のため に働くような組織市民行動に相当する行動がと られていたため, 組織市民行動の研究自体の蓄 積が少ない現状であった。加えて，日本に限ら ず米国以外の国で行われている組織市民行動の 研究では, 例外なく米国で開発された尺度をそ のまま自国語に翻訳して測定尺度として使用し てきた。

\section{3 組織市民行動を規定する要因}

これまでの先行研究における組織市民行動の 規定要因としては，(1)組織における公正さの認 知，(2)上司のリーダーシップ，(3)職場における 満足感, (4)組織サポート, (5)組織コミットメン 卜，6従業員の感情や気分 (7)性格的あるい は資質的要因 8人口統計的要因等が挙げら れる。この中で，組織市民行動を規定する要 因としてリーダーシップの関連性について以 下の研究で述べられている. Farh, Podsakoff, \& Organ ${ }^{9)}$ や Tansky ${ }^{10)}$ の研究では, 組織市民 行動を生起させる直接的要因として上司への信 頼感が必要である事を見出している. 上司の リーダーシップスタイルの中でも, 特に従業員 の組織市民行動を引き出しやすいとされている のが，支援的リーダーシップスタイルである事 はいくつかの研究で明らかにされている。例 えば, Smith et al. ${ }^{3)}$ やP Podsakoff et al. ${ }^{11)}$ では, リーダーが個々の従業員に対してこまめにアド バイスを与えていると評価されているほど, 従 業員の組織市民行動が高まる傾向であること が明らかとなっている (Netemeyer et al., ${ }^{12)}$; Settoon, Bennett, \& Linden, ${ }^{13)}$ でも同様の研究結 果が得られている)。また，組織市民行動を規 定する要因として組織サポートの関連性につい ては以下の研究で述べられている。組織サポー 卜は「組織が従業員の貢献をどのくらい評価 し，従業員がどのくらい満足のいく状態である かを気遣う程度に関する従業員認知」と定義さ れている (Eisenberger, Huntinton, Hitchinson, \& Sowa, $\left.{ }^{14)}\right)$. Van Yperen, Vanden Berg, \& 
Willering, ${ }^{15)}$ は困ったときに上司からサポートを 受けていると感じている従業員ほど, 組織市民 行動を起こしやすいようだと述べている.

\section{4 短期集合型組織における先行研究}

組織市民行動の研究において, スポーツイ ベントボランティアを対象とした研究は大後 ${ }^{16)}$ の 1 編である. 大後 ${ }^{16)}$ は, 2015年北海道マラソ ンの参加ランナーを支えるボランティア 600 名 を対象とし調查を実施した。 アンケートの調查 項目数は63項目で実施し, 分析モデルの仮説は 短期集合型組織の特徴を考慮し表 1 のとおり 7 つの仮説とし, 分析モデルは図2のとおりとし た.

リーダーのリーダーシップ行動については, 構成概念である「支援型」,「指示型」の下位次 元に「対個人」，「対チーム」の尺度を設けた． これは, 個人に対するリーダーシップ行動と チームに対するリーダーシップ行動に分けて, 自分のチームのリーダー行動をボランティア がそれぞれ評価し, 支援型リーダーシップの発 揮の程度と指示型リーダーシップの発揮の程度 に分け分析した. 分析の結果, リーダーがチー
ムに対して指示型リーダーシップを発揮する事 で，組織市民行動が促進された，リーダーの適 切な指示が職務をやり易くすることで自己効力 感を生むとともにチームでの仕事の進め方や判 断の仕方を共有するチームメンタルモデルを形 成し，それによって職務の満足感が醸成されて 組織市民行動が促進されたと考えられる.また, リーダーシップが発揮されない場合は, 自らの 経験を頼りに職務を推進することで組織市民行 動が促進される事を明らかとした。

\section{5 先行研究の問題点}

大後 ${ }^{16)}$ の調查個所は地方都市で開催されたマ ラソンイベントのボランティアを対象とした 1 遍のみであるため, 先行研究の成果を踏まえ他 のリサーチサイトでの研究の蓄積を行う必要が

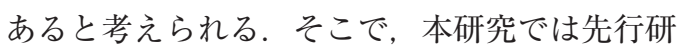
究と異なる都市部で開催される湘南国際マラソ ンを調査対象箇所とし研究を行う事とする.

\section{3. 本研究の仮説及び分析モデルの設定}

本研究で対象とする組織は, 大後 ${ }^{16)}$ と同様活動 期間が限定的で, 構成されるメンバーが当日初

表 1 大後 (2017) 研究の仮説

\begin{tabular}{|l|l|}
\hline 仮説 1 & ボランティア活動の場における経験はチームメンタルモデルに正の影響を与える \\
\hline 仮説 2 & チームメンタルモデルは職務満足感に正の影響を与える \\
\hline 仮説 3 & ボランティア活動の場における経験は自己効力感に正の影響を与える \\
\hline 仮説 4 & リーダーシップはチームメンタルモデルに正の影響を与える \\
\hline 仮説 5 & リーダーシップは自己効力感に正の影響を与える \\
\hline 仮説 6 & 自己効力感は職務満足感に正の影響を与える \\
\hline 仮説 7 & 職務満足感は組織市民行動に正の影響を与える \\
\hline
\end{tabular}

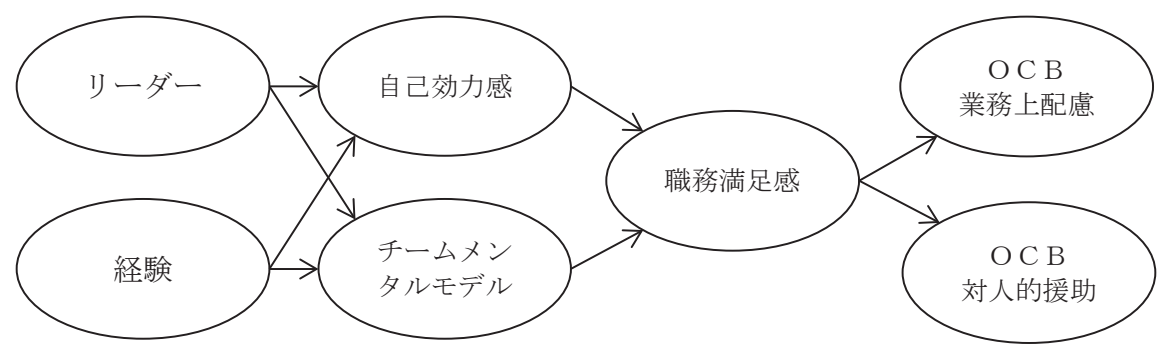

図2 大後 (2017) 分析モデル 
めて顔を合わせ事前に十分な打ち合わせができ ない等の特徴を持つ短期集合型組織である。 こで, 本研究では大後 ${ }^{16)}$ の先行研究の分析モデ ルを用いて分析する事とする．分析モデルは以 下のとおりである.

\section{1 本研究における組織市民行動の構成概念}

田中 ${ }^{17)}$ より，本研究に直接関わると考えられ る要素として, 組織構成員の行動に関する因子 である(1)対人的援助, (2)業務上の配慮の 2 因子 を使用することとする．先ず「対人的援助」は, ボランティア活動中において困っているメン バーがいれば，手助けする行動が行われるであ ろうと考えられるため構成概念とした。

次に「業務上の配慮」は, 他のメンバーから の質問に対して丁寧に答えたり仕事に役立つ情 報を共有するなどの行動が行われるであろうと 考えられるため構成概念とした。

\section{2 本研究における組織市民行動の促進要因}

第 1 に，ボランティアリーダーのリーダー シップの発揮の仕方についてである. 大会参加 者が 10,000 人を超える大規模マラソン大会を支 えるボランティアは, 年齢, 性別, ボランティ ア経験年数も異なることから, 以下の 2 つの リーダーシップタイプを分析に用いることとす る.

先ず，支援型リーダーシップである. Smith et al. ${ }^{3)}$ は，上司が部下に支援的であると評価さ れているほど組織市民行動の評価が高くなるこ とを明らかにしている.リーダーによる支援行 動は援助行動として知覚され, 互酬を感じ組織 市民行動が促進されやすいとされている.

また, Podsakoff ${ }^{7)}$ はリーダーとの信頼構築 やこまめにアドバイスを与えていると評価され るほど組織市民行動が高くなる傾向にある事を 明らかにした。このことから, 支援型リーダー シップを分析モデルに使用した.

本研究では支援型リーダーシップの定義を 「リーダーとボランティアが信頼を築き良好な 関係で業務を円滑に推進するためにリーダーが
必要な助言を友好的に行う行為」と定めた。次 に，指示型リーダーシップである．ボランティ アの中にはボランティア経験が少なく知識や対 応能力の低い者も存在する。このようなボラン ティアに対し，どのような行動を期待している のかをはっきり示し，職務中に必要な職務指示 を的確に行い課題達成の期待を高める必要があ る. そのため, 指示型のリーダーシップを分析 モデルに使用した。

本研究では指示型リーダーシップの定義を 「ボランティアに対し業務の進め方ややるべき こと等を明確に指示する行為」と定めた。

第 2 に, 自己効力感である. 自己効力感と は，自分のスキルを用いて自分には何がどのく らいできるのかという判断（力）の事である (Bandura, $\mathrm{A}^{18)}$ ). このような自己効力感を持 つことで，思いがけない問題が起こっても対処 できると確信することが，組織市民行動を促進 すると考えられる.

第 3 に，チームメンタルモデルである. チー ムメンタルモデルとは, チームが取組む課題の 内容や遂行の仕方, チームの特性やメンバー の特性に関する知識や心的表情（イメージ）が メンバー間で共有されていることを意味し, Johnson ${ }^{19)}$ は, チームでメンタルモデルが共有 されていることによってチームパフォーマンス にプラスの影響がもたらされることを示した。 Kraiger ${ }^{20)} ら は$, チームメンタルモデルを可視 化するための測定尺度の中に,「知識の構造化」 と「情報処理」を挙げている. 知識の構造化とは, 課題や技術あるいはお互いの役割など，チーム 活動に関してメンバーが保持している様々な知 識が関連付けられ，役立つよう構造化されてい る程度を示すものであり，チームメンバー間に おける情報の共通理解の程度を表している，次 に情報処理とは，チームで課題を遂行する過程 でメンバーが出会う様々な出来事に対して, 適 切な対処の仕方についての考え方をチーム活動 で活かす知識であり，チームメンバー間におけ る情報の共通理解の程度を表している.

これらは, チームで行うボランティア活動に 
有効と考えられることから要因に使用すること とする.

\section{3 分析モデルの設定}

本研究では， 2.2 より短期集合型組織にお いて促進要因であると考えられる, 上司のリー ダーシップ, 職務満足感, 従業員の感情や気分 を採用するが, 組織における公正, 組織コミッ トメント, 組織サポート, は短期集合型組織で の影響が少ないと考え大後 ${ }^{16)}$ 同様分析モデルか ら除外することとした。

\section{4 本研究における仮説}

\section{4. 1 経験, チームメンタルモデル, 職務満} 足感の関係

ボランティア活動の場における個々の経験を チームで情報交換, 共有することでチームメン タルモデルが促進するだろうとし，以下の仮説 を設定した。

仮説 1 ：ボランティア活動の場における経験は チームメンタルモデルに正の影響を与 える

次に, 職務満足感は仕事に伴って生じる肯定 的な主観的感情であり, Locke ${ }^{21)}$ は, 個人の仕 事の評価や仕事における経験からもたらされる 喜ばしい感情, もしくは肯定的な感情であると 定義づけている. チームメンタルモデルは, パ フォーマンスに正の影響を与えることから，活 動の場における経験で得られた正しい情報を チームで共有し活動に活かすことで職務満足感 につながるとし, 以下の仮説を設定した.

仮説 2 : チームメンタルモデルは職務満足感に 正の影響を与える

\section{4.2 ボランティア活動の場における経験と} 自己効力感の関係

経験と自己効力感の関係について林 ${ }^{22}$ は， あ る活動やタスクに関するポジティブな経験（楽 しい, 面白い, 達成感が得られた, 周囲の人達 から評価された, 認められた等) がその活動や タスクに関する自己効力感を向上させることを 示している.このことから, ボランティア活動
の場においてポジティブな経験をすることが自 己効力感を向上させるとし, 以下の仮説を設定 した。

仮説 3 : ボランティア活動の場における経験は 自己効力感に正の影響を与える

\section{4. 3 リーダーシップとチームメンタルモデ}

\section{ルの関係}

Stogdill ${ }^{23)}$ は, リーダーシップとは, 集団の 目標達成に向けてなされている集団の諸活動 に影響を与える過程であると定義づけている。 リーダーのリーダーシップ行動はチームという 集団での活動に影響を与える行動であると考え られるため, 以下の仮説を設定した.

仮説 4 ：リーダーシップはチームメンタルモデ ルに正の影響を与える

\section{4.4 リーダーシップと自己効力感の関係}

林 ${ }^{22)}$ によれば, リーダーの相互作用的行動や 情報の明確なフィードバックといったリーダー のリーダーシップ行動は自己効力感を促進させ る.このことから, 本研究において以下の仮説 を設定した。

仮説 5 ：リーダーシップは自己効力感に正の影 響を与える

\section{4.5 自己効力感と職務満足感の関係}

自己効力感が高まると職務満足感が高まると $\mathrm{Kickul}^{24)}$ は述べている.このことから, 本研究 において以下の仮説を設定した.

仮説 6 ：自己効力感は職務満足感に正の影響を 与える

\section{4.6 職務満足感と組織市民行動の関係}

Bateman, \& Organ $^{25)}$ では, 職務満足感が組 織市民行動を促進するとされていることから， 本研究において以下の仮説を設定した.

仮説 7 : 職務満足感は組織市民行動に正の影響 を与える

以上, 仮説 $1 \sim 7$ を踏まえ本研究における分 析モデルを図３に示すとおり設定した。リー ダーシップについては, 支援型リーダーシップ と指示型リーダーシップの比較検討を行うこと とする. 


\section{4. 研 究 方 法}

\section{1 調査対象}

本研究は, 2016年湘南国際マラソンの参加ラ ンナーを支えるボランティアリーダー 50 名及 びボランティア700名を対象とした. ボランティ アはNPO法人湘南スポーツコミュニティセン ターを通じて募集される。ボランティアリー ダー及びボランティアは事前に業務説明会が あるが，ボランティア作業当日の現場配置場所 は当日指示されるため, ボランティア同士は当 日初めて顔を合わせるメンバーが多い大会であ る.

\section{2 調査実施方法}

本研究の分析モデル（図3. 図4. 図6）よ りリーダーのどのようなリーダー行動が組織市 民行動に影響を与えるのかを調べるため, 調査 票の配布は作業グループ単位でボランティア リーダーとボランティアをセットにし配布し た。

調査方法は, 無記名による郵送質問紙法で
行った。調查票の表紙には, 個人情報の取扱い 等調查倫理に関する注意事項を記載した。調査 票記入時間は 10 分〜 20 分を想定した。 尺度水 準は, 順序尺度法（リッカート尺度， 7 件法) を用いた。調查票の回収期間は大会終了後の 2016年12月 4 日〜 12月 18 日の 2 週間以内とし た。

\section{3 分析に使用した測定尺度}

分析の枠組みに対して 3.3 で設定した分析 モデルに即し, 本研究の測定尺度を設定した。 その結果全体の調査項目数は63項目となった. リーダーのリーダーシップ行動については, 構 成概念である「支援型リーダーシップ」,「指示 型リーダーシップ」の下位次元に「対個人」,「対 チーム」の尺度を設けた。 これは，個人に対す るリーダーシップ行動とチームに対するリー ダーシップ行動に分けて, 自分のチームのリー ダーの行動をボランティアが評価する指標であ り，支援型リーダーシップの発揮の程度と指示 型リーダーシップの発揮の程度に分けそれぞれ 分析することとした.

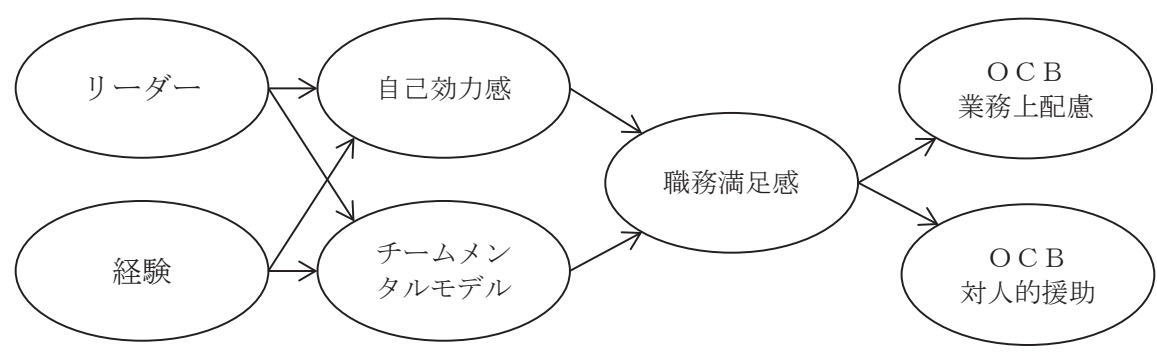

図3本研究の分析モデル

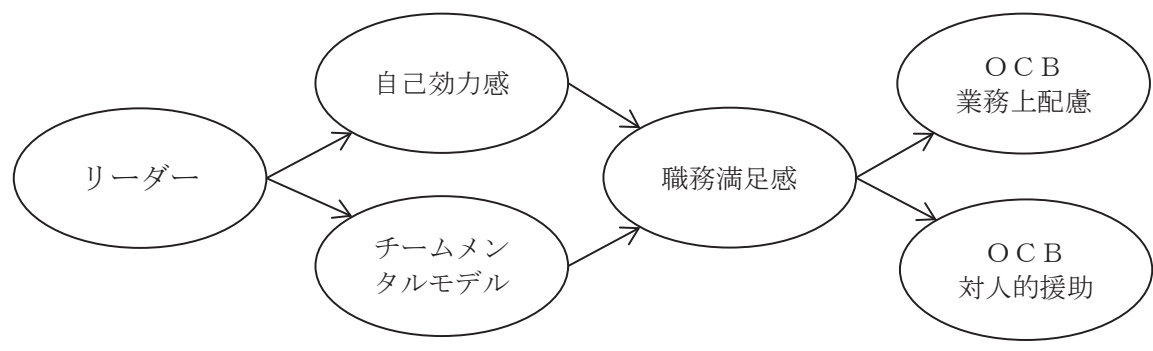

図4 本研究の分析モデル（修正後） 


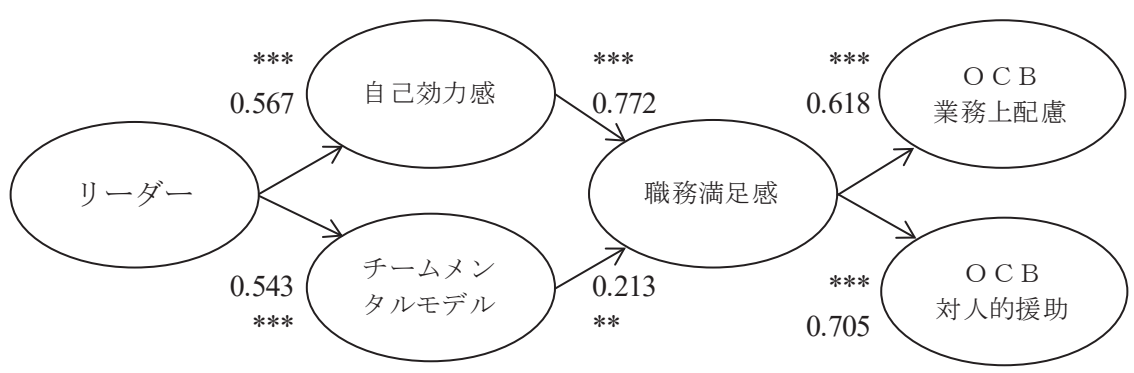

図 5 支援型リーダーシップが参加者個人に与える組織市民行動促進要因

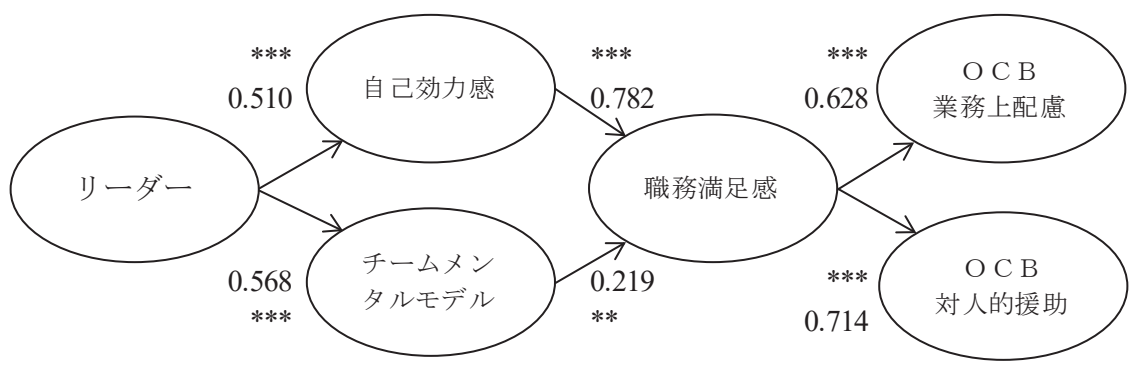

図6 支援型リーダーシップがチームに与える組織市民行動促進要因

\section{4 分析方法}

分析は以下のとおり行う。第 1 に，本研究の 分析で用いる構成概念を明らかにするために因 子分析を行う。第 2 に, 図3. 図4. 図6の分 析モデルに従って複数の説明変数を用いて組織 市民行動に影響を与える要因相互の因果関係を 明らかにするため, リーダーシップのタイプ別 に共分散構造分析を行う。第 3 に，第 2 の結果 から組織市民行動を最も促進する要因群を明ら かにするために $t$ 検定を行う.

\section{5. 結果}

\section{1 有効回答者の属性と基本統計量の確認}

リーダーは50名に配布し26名から回答がなさ れた（回収率52.0\%)。男性22名 $(84.6 \%)$, 女性 4 名 $(15.4 \%)$, 年齢は60歳代が最も多く 8 名 $(30.8 \%)$, 参加回数は $6-11$ 回が最も多く11名 (42.3\%), 参加動機は自発的参加が 22 名 (84.6\%). 職業は会社員が最も多く15名 $(57.7 \%)$ であっ た.

一方，フォロアーは600名に配布し203名から
回答（回収率33.8\%）がなされた。男性119名 (58.6\%)，女性80名 $(39.4 \%) ，$ 年齢は60歳代が 最も多く64名 $(31.5 \%)$, 参加回数は $1-5$ 回が 最も多く85名 (41.9\%)，参加動機は自発的参加 が178名 (87.7\%)。職業は会社員が最も多く72 名（35.5\%）であった。

\section{2 組織市民行動とその促進要因の構成概念}

因子分析の結果を表 2 に示す。構成概念にお ける探索的因子分析の結果，「リーダーシップ (支援型, 指示型 $) 」 「$ チムムメンタルモデル（情 報の共通理解, メンバー同士の共通理解)」,「自 己効力感」,「組織市民行動：対人的援助」,「組 織市民行動：業務上配慮」,「職務満足感」の構 成とした，次に，確認的因子分析を行った。相 関係数の確認では, 全相関係数を求め相関係数 が 0.3 以下で有意確率 $\mathrm{p}>0.05$ となった変数を慎 重に見極め，経験因子のうち「能動的修得」の 2 変数は削除した。

次に因子の内的整合性を示すクロンバックの $\alpha$ 係数は経験因子の 3 変数が.497 と基準である 


\section{表2 因子分析結果}

\begin{tabular}{|c|c|c|c|c|c|}
\hline \multirow{2}{*}{ 測定尺度 } & \multicolumn{2}{|c|}{ 因子 } & \multirow{2}{*}{ 因子名 } & \multirow{2}{*}{$a$ 係数 } & \multirow{2}{*}{\begin{tabular}{|c|c|c|} 
抽出後 \\
負荷量平方和
\end{tabular}} \\
\hline & 1 & 2 & & & \\
\hline \multicolumn{6}{|l|}{ 口構成概念：支援型リーダーシップ 下位次元：対個人 } \\
\hline リーダーは仕事に関してあなたの意見を重視してくれましたか & 0.702 & \multirow{2}{*}{-} & \multirow{2}{*}{ 尊重 } & \multirow{2}{*}{0.912} & \multirow{2}{*}{91.9} \\
\hline リーダーはあなたの意見を聞きながら仕事を進めていましたか & 0.702 & & & & \\
\hline リーダーは仕事の進め方についてあなたに適切な助言をしてくれましたか & \multirow{4}{*}{ - } & 0.808 & \multirow{4}{*}{ 声掛け } & \multirow{4}{*}{0.876} & \multirow{4}{*}{73.0} \\
\hline リーダーはあなたに対して友好的で親しみやすかったですか & & 0.795 & & & \\
\hline リーダーはあなたが仕事に対して自信が持てるような言葉をかけてくれましたか & & 0.895 & & & \\
\hline リーダーはあなたに能力がある事を認めて声をかけてくれましたか & & 0.704 & & & \\
\hline \multicolumn{6}{|l|}{ 口構成概念：支援型リーダーシップ 下位次元：対チーム } \\
\hline リーダーは仕事に関してチームの意見を重視してくれましたか & 0.616 & \multirow{2}{*}{-} & 酋禹 & & \\
\hline リーダーはチームの意見を聞きながら仕事を進めていましたか & 0.616 & & 學里 & 0.879 & 89.2 \\
\hline リーダーは仕事の進め方についてチームに適切な助言をしてくれましたか & & 0.809 & & & \\
\hline リーダーはチームに対して友好的で親しみやすかったですか & & 0.831 & 士声扑人t & & \\
\hline リーダーは仕事に対してチームが自信を持てる言葉をかけてくれましたか & - & 0.946 & 声啩け & 0.907 & 78.2 \\
\hline リーダーはチームに能力がある事を認めて声をかけてくれましたか & & 0.831 & & & \\
\hline 口構成概念：指示型リーダーシップ 下位次元：対個人 & & & & & \\
\hline リーダーはやるべきことを明確にあなたに指示してくれましたか & 0.947 & & & & \\
\hline リーダーは仕事の進め方をあなたに指示してくれましたか & 0.946 & - & 明確な指示 & 0.929 & 87.8 \\
\hline リーダーは仕事の優先順位をあなたに指示してくれましたか & 0.821 & & & & \\
\hline 口構成概念：指示型リーダーシップ 下位次元：対チーム & & & & & \\
\hline リーダーはやるベきことを明確にチームに指示してくれましたか & & 0.944 & & & \\
\hline リーダーは仕事の進め方をチームに指示してくれましたか & - & 0.951 & 明確な指示 & 0.961 & 92.7 \\
\hline リーダーは仕事の優先順位をチームに指示してくれましたか & & 0.937 & & & \\
\hline 口構成概念 : チームメンタルモデル 下位次元 : 問題や状況の把握 & & & & & \\
\hline どのように状況の把握をすべきかチームで共通理解していましたか & 0.860 & & & & \\
\hline チームとして仕事全体の流れを共通理解していましたか & 0.908 & - & 状呮井 0 开解 & 0.027 & 822 \\
\hline 対処の仕方が正しいかどうかチームで共通理解していましたか & 0.933 & & 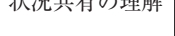 & 0.927 & 82.2 \\
\hline 特別な問題が起きたかどうかの判断がチームで行われていましたか & 0.793 & & & & \\
\hline 口構成概念：チームメンタルモデル 下位次元：メンバー間理解 & & & & & \\
\hline 他のチームメンバーの役割を共通理解していましたか & 0.752 & & & & \\
\hline 他のチームメンバーの得意な分野を共通理解していましたか & 0.880 & & メンバー同士の & & \\
\hline 他のチームメンバーがどのように対処すればうまくいくか共通理解していましたか & 0.931 & & 共通理解 & 0.889 & 75.5 \\
\hline リーダーが不在の時は誰に相談すればよいかをチームメンバー間で共通理解していましたか & 0.722 & & & & \\
\hline 口構成概念 : チームメンタルモデル 下位次元 : メンバー援助 & & & & & \\
\hline 他のメンバーがミスをしても前向きな言葉をかけましたか & 0.903 & & & & \\
\hline 他のメンバーが困っているときは助けましたか & 0.769 & - & 他メンバーへの & 0.842 & 76.0 \\
\hline 落ち込んでいるメンバーがいるときは励ましましたか & 0.733 & & & & \\
\hline 口構成概念：自己効力 下位次元：感情的覚醒 & & & & & \\
\hline 今回のボランティア活動に前向きに取組めましたか & 0.692 & - & & & \\
\hline 今回のボランティア活動に楽しんで取組めましたか & 0.692 & - & 感情覚醒 & 0.906 & 91.5 \\
\hline 口構成概念：自己効力 下位次元：自己効力感 & & & & & \\
\hline 始めはうまくいかない仕事でもできるまでやり続けましたか & 0.763 & & & & \\
\hline 最後まであきらめないで業務を行いましたか & 0.857 & - & & 0862 & 712 \\
\hline 出だしでつまづいてもすぐに諦めず頑張りましたか & 0.801 & & 目己㕮力感 & 0.862 & 71.2 \\
\hline 失敗しても一生懸命やろうと思いましたか & 0.721 & & & & \\
\hline 口構成概念：組織市民行動 下位次元：対人的援助 & & & & & \\
\hline チームメンバーの仕事上のトラブルは進んで手助けしましたか & 0.905 & & & & \\
\hline 多くの仕事を抱えているチームメンバーに手助けしましたか & 0.832 & - & メンバー援助 & 0.842 & 76.5 \\
\hline チームメンバーに手を貸せるように準備していましたか & 0.683 & & & & \\
\hline 口構成概念：組織市民行動 下位次元：職務配慮 & & & & & \\
\hline 一度受けた仕事は最後まで責任を持って実行しましたか & 0.759 & & & & \\
\hline チームメンバーからの疑問や質問は丁寧に答えましたか & 0.66 & & & & \\
\hline チームメンバーに迷惑にならないよう注意して行動しましたか & 0.856 & - & 業務上配虑 & 0.858 & 71.4 \\
\hline 自分の仕事に注意深く取り組みましたか & 0.871 & & & & \\
\hline 口構成概念：職務満足 & & & & & \\
\hline 全体としてこの活動に満足していますか & 0.768 & & & & \\
\hline 活動を通じて自分の成長や進歩を感じていますか & 0.683 & - & 満足咸 & 0798 & 630 \\
\hline あなたのこれまでの経験が活かせる職務を与えられましたか & 0.716 & & 淈定感 & 0.798 & 63.0 \\
\hline あなたの与えられた仕事量に満足していましたか & 0.681 & & & & \\
\hline
\end{tabular}




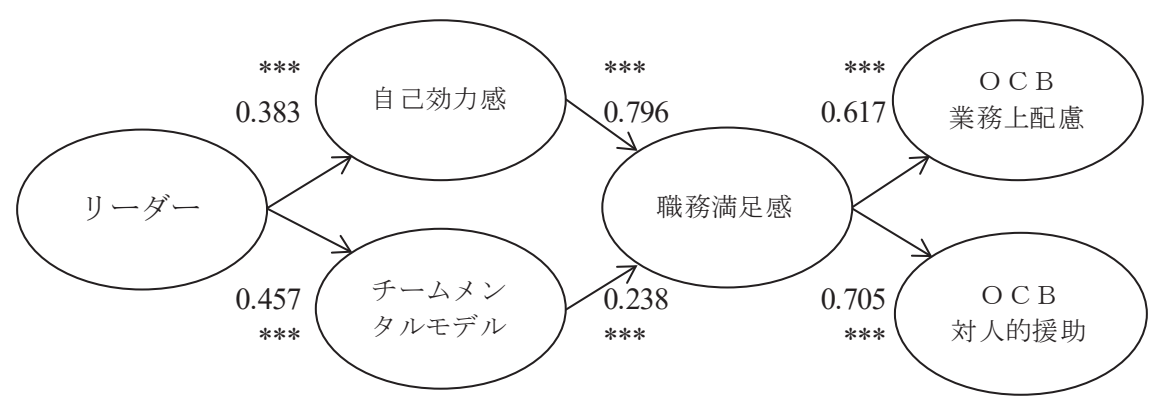

図7指示型リーダーシップが参加者個人に与える組織市民行動促進要因

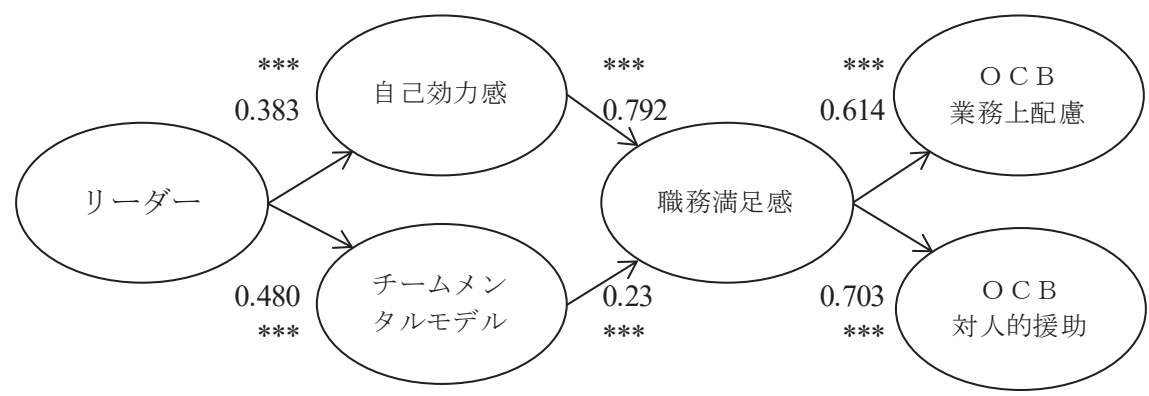

图８指示型リーダーシップがチームに与える組織市民行動促進要因

0.80を大きく下回った事から分析モデルから除 外した.この結果, 図 3 の本研究モデルの分析 モデルを図4に修正した。先行研究のモデルと 異なり, 経験因子が削除されたがその理由は考 察で述べることとする.

\section{3 組織市民行動促進要因の分析}

本節では，図2の分析モデルに従いスポーツ イベントボランティアの組織市民行動の促進要 因を確認するため，5．20結果を踏まえ，支 援型リーダーシップ, 指示型リーダーシップ別 に共分散構造分析を行った結果を示す。それぞ れで複数のモデルを比較した結果, 適合度が良 好な值を示した図5～図8のモデルを採用し た. パス解析モデルの矢印にある数值は標準化 推定值を示す.

支援型リーダーシップが参加者個人に与える 組織市民行動促進要因の分析結果は, 図 5 に示 したとおりとなった，適合度指数は, GFI = .744, $\mathrm{GFI}=.703, \mathrm{RMR}=.147, \mathrm{CFI}=.866, \mathrm{RMSEA}$
$=.081$ となり適合度指標の值はいずれも許容で きるレベルであり，このモデルはデータに適合 していると考えられる。尚，モデルの適合度を 評価するための統計的指標は $\mathrm{GFI}=0 \sim 1.0$ 以 内, $\mathrm{AGFI}=1.0$ に近く $\mathrm{GFI} \geqq \mathrm{AGFI}, \mathrm{RMR}=0$ に近く, CFI=1.0に近いこと, RMSEA =0.1 以下とした。

次に，支援型リーダーシップがチームに与え る組織市民行動促進要因の分析結果は図6に示 したとおりとなり，分析の適合度指数は，GFI $=.729, \mathrm{AGFI}=.687, \mathrm{RMR}=.146, \mathrm{CFI}=.863$, RMSEA = .084となり適合度指標の值はいず れも許容できるレベルであり,このモデルは デー夕に適合していると考えられる，尚，モ デルの適合度を評価するための統計的指標は $\mathrm{GFI}=0 \sim 1.0$ 以内, $\mathrm{AGFI}=1.0$ に近くGFI $\geqq$ AGFI, RMR = 0 に近く, CFI = 1.0に近いこと, RMSEA =0.1以下とした.

指示型リーダーシップが参加者個人に与える 組織市民行動促進要因の分析結果は図7に示し 
表 3 総合効果一覧

\begin{tabular}{|c|c|c|c|c|c|c|}
\hline リーダーシップタイプ & 相手 & \multicolumn{3}{|c|}{ パス解析 } & 総合効果 & 総合効果計 \\
\hline \multirow{4}{*}{ 支援型リーダー } & \multirow{2}{*}{ 対個人 } & 自己効力感 & $\rightarrow$ & $\mathrm{OCB}$ & 0.58 & \multirow{2}{*}{0.73} \\
\hline & & チームメンタル & $\rightarrow$ & $\mathrm{OCB}$ & 0.15 & \\
\hline & \multirow{2}{*}{ 対チーム } & 自己効力感 & $\rightarrow$ & $\mathrm{OCB}$ & 0.54 & \multirow{2}{*}{0.70} \\
\hline & & チームメンタル & $\rightarrow$ & OCB & 0.17 & \\
\hline \multirow{4}{*}{ 指示型リーダー } & \multirow{2}{*}{ 対個人 } & 自己効力感 & $\rightarrow$ & $\mathrm{OCB}$ & 0.40 & \multirow{2}{*}{0.55} \\
\hline & & チームメンタル & $\rightarrow$ & $\mathrm{OCB}$ & 0.14 & \\
\hline & \multirow{2}{*}{ 対チーム } & 自己効力感 & $\rightarrow$ & $\mathrm{OCB}$ & 0.40 & \multirow{2}{*}{0.54} \\
\hline & & チームメンタル & $\rightarrow$ & $\mathrm{OCB}$ & 0.15 & \\
\hline
\end{tabular}

\section{表 $4 \mathrm{t}$ 検定結果}

\begin{tabular}{|l|c|c|c|c|}
\hline 総合効果得点 $\mathrm{t}$ 検定 & $\mathrm{N}$ & 平均值 & 標準偏差 & $\mathrm{t}$ \\
\hline \hline 支援型リーダー & 8 & 0.1794 & 0.107 & \multirow{2}{*}{2.44} \\
\cline { 1 - 4 } 指示型リーダー & 8 & 0.1031 & 0.071 & \\
\hline
\end{tabular}

たとおりとなった。分析の適合度指数は, GFI $=.754, \mathrm{AGFI}=.711, \mathrm{RMR}=.171, \mathrm{CFI}=.873$, $\mathrm{RMSEA}=.084$ となり適合度指標の值はいず れも許容できるレベルであり，このモデルは データに適合していると考えられる。尚, モ デルの適合度を評価するための統計的指標は $\mathrm{GFI}=0 \sim 1.0$ 以内, $\mathrm{AGFI}=1.0$ に近くGFI $\geqq$ AGFI, RMR = 0 に近く, CFI = 1.0に近いこと, RMSEA = 0.1以下とした.

最後に, 指示型リーダーシップがチームに与 える組織市民行動促進要因の分析結果は, 図8 に示したとおりとなった。適合度指数は, GFI $=.759, \mathrm{AGFI}=.717, \mathrm{RMR}=.170, \mathrm{CFI}=.878$, $\mathrm{RMSAE}=.084$ となり適合度指標の值はいず れも許容できるレベルであり, このモデルは データに適合していると考えられる. 尚, モ デルの適合度を評価するための統計的指標は $\mathrm{GFI}=0 \sim 1.0$ 以内, $\mathrm{AGFI}=1.0$ に近 $く \mathrm{GFI} \geqq$ AGFI, RMR = 0 に近く, CFI = 1.0に近いこと, RMSEA =0.1以下とした.

\section{4 総合効果の比較}

本節では 5.3 で得られた結果から,リーダー シップのタイプ別で組織市民行動の促進要因が
どのように影響したのかを確認するため, パス 解析の結果を用いリーダーシップから組織市民 行動への総合効果の得点を比較した. 表 3より 組織市民行動の促進効果を総合的に判断するた め, 総合効果累計值を確認すると0.73で支援型 リーダーシップが個人に対して影響を与える程 組織市民行動が高くなることが明らかとなっ た。

次に, 支援型, 指示型のリーダーシップタイ プ別ではどちらがより組織市民行動を促進する のかを確認するため, 総合効果得点の $t$ 検定を 行った. その結果, 表 4のとおり $\mathrm{t}(7)=2.44$, $\mathrm{p}<0.05$ となり, 支援型リーダーシップの方が 組織市民行動の促進効果が高い結果となった。

\section{6. 短期集合型組織における組織市民行動の促 進要因に関する考察}

\section{1 支援型リーダーシップの影響}

本研究に拈いて，5.5より支援型リーダー シップが個人に与える影響が大きいほど組織市 民行動が促進される事が明らかとなった.

では, なぜこのリサーチサイトでは先行研究 と異なる結果となったのか, 湘南国際マラソン はどのようなボランティアリーダーとボラン 
ティアが活動していたのだろうか. 分析結果よ り，ボランティアはリーダーから尊重や声掛け という支援型リーダーシップを受け，信頼感を 生起させ自分ならやれるという自己効力感を 生むとともに, チームでの仕事の進め方や判断 の仕方を共有するチームメンタルモデルを形成 し，それによって職務に対する満足感が得られ 組織市民行動が促進されたと考えられる。長期 集合型組織を対象とした先行研究においても, 個人に対する支援型リーダーシップによって組 織市民行動が促進される事が明らかになってい る。

$\mathrm{Smith}^{3)}$ は, 長期集合型組織の従業員を対象 とした研究において, 上司が部下に支援的で あると評価されているほど組織市民行動の評 点が高くなることを明らかにし, Konovsky, \& $\mathrm{Pugh}^{4)}$ は組織市民行動を生起させる直接的要 因として上司への信頼感を見出している.

一方, 長期集合型組織と短期集合型組織では 異なる業務遂行環境であるが, なぜ本リサーチ サイトでは短期集合型組織においても支援型 リーダーシップが組織市民行動を高めたのか次 節で考察することとする.

\section{2 ボランティア運営組織と支援型リー ダーシップを発揮するリーダーの関係}

本節では，なぜ本リサーチサイトのリーダー は短期集合型組織において個人に対し支援型 リーダーシップを発揮できたのか, その要因に ついてボランティアの運営方針に着目し考察を 行った.

本リサーチサイトのボランティア運営を行っ ているNPO法人湘南スポーツコミュニティセ ンターでは, ボランティアリーダーの再参加率 が高いことから, 担当する業務箇所をなるべく 前年同様配置し当該箇所での過去のリーダー経 験を最大限活かせるよう配慮している。また， 大会終了後にはリーダーを対象とした活動の振 り返りを行い翌年の運営に活かしている.

すなわち, 本リサーチサイトのボランティア リーダーは, この現場に精通し豊富な経験と
チームの業務をこなすための高い知識を持った リーダーが多数指揮を執っていると考えられ る.

このようなリーダーは実力があり，活動中の チーム状況を見通せる俯瞰力を持っていると考 えられるため, 状況に応じてボランティアを尊 重し声掛けを行う事でボランティアから信頼を 得るなどの，支援型リーダーシップを発揮する ことが可能であると考えられる，また，このよ うな経験を積んだリーダーは，活動中における 業務内容の変更や咄嗟に判断が求められる救護 対応等が発生したとしても, 冷静に対処し業務 全体を包括的にマネジメントすることが可能で ある。

\section{7. 本研究と先行研究の相違点に関する考察}

\section{1 組織別支援型リーダーシップ発揮の比較}

本研究では, 個人に対して支援型リーダー シップを発揮することで組織市民行動が促進さ れた.この結果は, Smith et al. ${ }^{3)}$ やPodsakoff et $\mathrm{al}^{11)}$ の研究同様の結果となった。 しかし, 長 期集合型組織と短期集合型組織とでは異なる特 徵がある。

そこで，両組織間における支援型リーダー シップにどのような差があるのか検討する.

まず，長期集合型組織のリサーチサイトは企 業や学校等に雇用されている従業員等とされて いることから，タスクを進める中でじっくりと 時間をかけ従業員等の力量やパーソナリティー 等を理解することができ, 相互の信頼関係が成 り立つ中で支援型リーダーシップを発揮する 事ができる。一方，短期集合型組織においては 活動が短期であるため, じっくりと時間をかけ ボランティア個々の力量やパーソナリティー等 を把握することができない，お互いを理解しあ える事は困難であり，相互の信頼関係が築きに くい環境である.しかし， 6.2 で記載したよ うなボランティア運営を行う事で, 支援型リー ダーシップを発揮できるリーダーが育成され る.

すなわち短期集合型組織であっても，ボラン 
ティアが明るく楽しく友好的な雲囲気で作業が 行える等, 支援型リーダーシップが発揮され, ひいては組織市民行動が促進されることが推測 される。

\section{8. 結}

\section{論}

\section{1 結果の要約}

本研究は, 湘南国際マラソンに参加するス ポーツボランティアリーダーとボランティアを 対象に組織市民行動の促進要因を明らかにし た. 分析の結果, リーダーが個人に対して支援 型リーダーシップを発揮することでボランティ アの組織市民行動が最も促進される事が明らか となった。

\section{2 今後の課題}

本研究では, アンケート調査の定量データに 基づきリーダーシップの分析を行った. 今後は リーダーとボランティアとのいかなる関係性が 組織市民行動促進に影響を与えたのかという点 に焦点を当てた研究が必要と考えられる，具体 的には, 現場のリーダーを参与観察し豊富な 経験とチームの業務をこなすための高い知識 を持ったリーダーがどの場面でどのようなリー ダーシップを発揮しているのか更に調査してい く必要がある。

\section{参 考 文 献}

1) Organ, D.W. ; Organizational citizenship behavior: The good soldier syndrome. Lexington Books, 1988.

2 ）田中堅一郎；『従業員が自発的に働く職場をめ ざすために』, ナカニシヤ出版, p.11. 154, 2004.

3 ) Smith, C.A., Organ, D.W., \& Near, J.P. ; Organizational citizenship behavior : Its nature and antecedents. Journal of applied Psychology, 68, pp.653-663, 1983.

4 ) Konovsky, M.A., \& Pugh, S.D. ; Citizenship behavior and social exchange, Academy of management journal, 37, pp.656-669, 1994.

5 ) Katz, D., \& Kahn, R.L. ; the socoal psychology of organizations. New York : Wiley, 1996.
6 ) Podsakoff, P.M., MacKenzie, S.B., \& Hui, C. ; Organizational citizenship behaviors and managerial evaluations of employee performance: A review and suggestions for future research, Research in personal and human resources managemnent (Vol.11, pp.1-40). Greenwich : JAI Press, 1993.

7 ) Podsakoff, P.M., MacKenzie, S.B., Moorman, R.H., \& Fetter, R. ; Trasformational leader behaviors their effects of follower's trust in leader, satisfaction, and organizational citizenship behaviors, Leadership Quarterly, 1, 1-7-142, 1990.

8 ) Van Dyne, L., Gtaham,J.W., \& Dienesch, R.M.; Organizational citizenship behavior Construct redefinition, measurement, and validation, Academy of Management Journal, 37, pp.765802, 1994.

9 ) Farth, J.L., Podsakoff, P.M., \& Organ, D.W. ; Accounting for organization citizenship behaviors : Leader fainess and task scope verdud satisfaction, Journal of Management, 16, pp.705-721, 1990.

10) Tansky, J.W. ; Justice and organizational citizenship behavior : What is relationship? Employee Responsibilities and Rights Journal, 6, pp.195-207, 1993.

11) Podsakoff, P.M., MacKenzie, S.B., Moorman, R.H., \& Fetter, R. ; Transformational leader behaviors their effects of follower's trust in leader, satisfaction, and organizational citizenship behaviors, Leadership Quarterly, 1, 1-7142, 1990.

12) Netemeyer, R.G., Boles, J.S., McKee, D.O., \& McMurrian, R. ; An investigation into the antecedents of organizational citizenship behavior in a personal selling context, Journal of Marketing, 61, pp.85-98, 1997.

13) Setton, R.P., Bennett, N., \& Linden, R.C. ; Social exchange in organizations : Preceived organizational support, leader-member exchange, and employee reciprocity. Journal of applied Psychology, 81, pp.219-227, 1996.

14) Eisenberger, R., Huntionton, R., Hitchison, S., \& Sowa, D. ; Perceived organizational 
support, Journal of Applied Psychology, 71, pp.500-507, 1986.

15) Van Yperen, N.W., Van den Berg, A.E., \& Willering, M.C. ; Towards a better understanding of the between participation in decision-making and organizational citizenship behavior, Journal of Occupational and Organizational Behavior, 72, pp.377-392, 1999.

16）大後茂雄; 北海道マラソンボランティアにお ける組織市民行動の促進要因, 日本学習社会学 会第13号, pp.90-98, 2017.

17）田中堅一郎; 日本版組織市民行動の研究, 産業・ 組織心理学研究, 15, pp.77-88, 2002.

18) Bandura, A. ; Self-efficacy : The Exercise of control. W.H. freeman \& Co., pp.42-44, 1997.

19) Johnson-Laird, P.N. ; Mental models. Cambridge, MA : Harvard University Press, 1983.

20) Kraiger, K., Ford, J.K., \& Sales, E. ; Application of cognitive, skill-based, and affective theories of learning outcomes to new methods of training evaluation. Journal of Applied
Psychology, 78, pp.311-328, 1993.

21) Locke, E. A. ; The nature and causes of job satisfaction. In M. D. Dunnette (Ed.), Handbook of industrial and organizational psychology. Chicago : Rand McNally, 1976.

22）林 伸二; 人と組織を変える自己効力感, 同文 舘出版, 2014.

23) Stogdill, R. M. ; Handbook of leadership : A survey of theory and research, New York, NY, US : Free Press, 1974.

24) Kickul, J., F. Wilson, D. Marlino \& S.D. Barbosa ; Are misalignments of Perceptions and self-efficacy Causing Gender Gaps in Entrepreneurial Intentions among Our Nation's teens?, Journal of Small Business and Enterprise Development, 15(2), pp.321-335, 2008.

25) Bateman, T.S., \& Organ, D.W. ; Job satisfaction and the good soldier: The relationship between affect and employee "citizenship." Academy of Management Journal, 26, pp.587595, 1983. 